\title{
A koalíciós haderők által alkalmazott fegyverrendszerek a jemeni konfliktusban - avagy eröltetett beszerzések, kétséges eredmények?
} Employed Weapon Systems by the Coalition Forces in Yemen - Forced Procurements, Doubtful Results?

\begin{abstract}
Absztrakt
A rendkívül sokszereplös jemeni konfliktus több olyan elemet is hordoz magában, amely elemzésre érdemes. A 2015-ben kezdödött - több térségbeli arab államot is magában foglaló - koalíciós katonai intervenció sok szempontból érdekes tapasztalatokat hozott. A koalíció két legerösebb és müveleti szempontból legaktívabb tagja Szaúd-Arábia és az Egyesült Arab Emirátusok. Mindkét állam hadereje szinte teljes spektrumát felvonultatta, valamennyi haderönemük kivette részét a müveletekböl. A szaúdiak és az Emirátusok részvételében közös pont a nagy mennyiségü és igen fejlett-elsősorban amerikai és európai-haditechnika alkalmazása. A konvencionális fegyverek nagyarányú bevetésének azonban nem egységes a mérlege; a hatékonyság, a pontosság és az eredményesség terén egyaránt komoly kritikák fogalmazódtak meg. A tanulmány a két ország által bevetett haditechnikai eszközöket, valamint azok alkalmazásának tapasztalatait vizsgálja.
\end{abstract}

Kulcsszavak: Jemen, Szaúd-Arábia, Egyesült Arab Emirátusok, légi csapás, közeli légi támogatás, blokád, járulékos veszteség 


\begin{abstract}
The multi-stakeholder Yemen conflict has a lot of elements which are worth analysing. The coalition form military intervention, which occurred in 2015 and consisted of more Arabic states from the region, had interesting experiences in many ways. From military aspects, the two strongest and most active members of the coalition are Saudi Arabia and the United Arab Emirates. Both of them have deployed almost their entire army, all of the different service branches have been used during the operations. A common characteristic in both forces is the extensive use of state of the art military equipment, mainly from U.S. and European sources. However, the result of their conventional equipment's deployment is not so obvious: we will see significant criticism regarding the efficiency, accuracy and success. This document will examine the deployed military equipment and the experiences of their use.
\end{abstract}

Keywords: Yemen, Saudi Arabia, United Arab Emirates, air strike, close air support, blockade, collateral damage

\title{
1. Bevezetés
}

Jemen hét éve színtere egy rendkívül bonyolult szövetségi politikákkal terhelt, súlyos harcokat és komoly civil áldozatokat eredményező fegyveres konfliktusnak. A konfliktus polgárháborúként vette kezdetét még 2014-ben a kormányerők és az évtizedes felkelő múlttal rendelkező húti erők fegyveres alakulatai között. A Hadi-kormány sikeres elüzését és több kulcsfontosságú város felkelők általi elfoglalását követően egy Szaúd-Arábia vezette, több nemzet részvételével létrejött koalíció katonai intervenciót hajtott végre az országban az előzőleg hivatalban lévő kormány hatalmának visszaállítása érdekében. Ezzel párhuzamosan Irán egyre jelentősebb pénzügyi, katonai és technikai támogatásban részesítette a húti felkelőket, a szakértők szerint klasszikus „ "helyettesítő" háborút kirobbantva. ${ }^{2}$ Ezen egyértelmű törésvonal mellett számos helyi milícia, felkelőcsoport, illetve több terrorszervezet is aktív az országban, támadásokat végrehajtva mindkét polgárháborús fél ellen. Az Egyesült Államok a kezdetektől katonai hírszerzési és logisztikai eszközökkel támogatja a szaúdi koalíciót, míg több európai ország fegyverekkel segítette a különböző harcoló feleket. A hosszú távon is fenntartható megoldással nem kecsegtető konfliktus jellemzője a kirívóan magas civil halálozási ráta. ${ }^{3}$

A Jemenben jelenleg is zajló fegyveres konfliktus ${ }^{4}$ tehát az elmúlt évtizedekben - még az egyébként fegyveres cselekményekkel meglehetősen "gazdagon ellátott" közel-keleti régióban is - kiemelkedő volumenü és intenzitású harcokat, a fegyveres

Jonathan Saul: Exclusive: Iran Revolutionary Guards find new route to arm Yemen. Reuters, 2017. augusztus 1.

Nadwa Al-Dawsari: Running around in circles: How Saudi Arabia is losing its war in Yemen to Iran. Middle East Institute, 2020. március 3.

4 A 2015-ben kirobbant konfliktus kezdetben polgárháborús jellemzőket mutatott, majd külső hatalmak beavatkozását lehetett nyomon követni egészen napjainkig, a továbbiakban összefoglalóan „konfliktusként” hivatkozom az eseményekre. 
erők széles körü bevetését, valamint rendkívül nagy mennyiségü és vegyes összetételü fegyverzet alkalmazását eredményezte. A koalíció ${ }^{2}$ katonai műveleteiben túlsúllyal rendelkező Szaúd-Arábia és az Egyesült Arab Emirátusok (Emirátusok) nagyszámú fejlett (elsősorban nyugati-európai vagy amerikai eredetü) haditechnikai eszközt is felvonultatott a múveletekben, ezen eszközök bevetési tapasztalatai azonban még a visszafogott kritikák szerint sem egységesen pozitívak. ${ }^{6}$ Számos térségbeli és nemzetközi kritika érte a feleket, mindenekelőtt a jelentős számú civil áldozat, továbbá a nem jól szervezett műveletek és a fejlett haditechnikai eszközök „rossz kezekbe" kerülése okán. Felmerül a kérdés, hogy a - koalíció legnagyobb tagjai esetében kiemelkedő védelmi költségvetéssel, látszólag korlátlan technikai lehetőségekkel rendelkező haderőknek miért nem sikerült látványosabb és tartósabb eredményeket elérniük, illetve ezen eszközök alkalmazása milyen okokból járt magas járulékos veszteségekkel?

Jelen tanulmányban a jemeni konfliktust a bevetett haditechnikai eszközök szempontjából, illetve múveleti oldalról kívánom megvizsgálni. Arra keresem a választ, hogy a jemeni kormánycsapatokat támogató erők pontosan milyen haditechnikai eszközöket alkalmaztak, ezeket milyen forrásból szerezték be és milyen fő problémák jelentkeztek az alkalmazás során? E problémák alapvetően technikai jellegüek vagy az alkalmazott harceljárásból fakadtak? A fegyverek bevetésének milyen közvetlen és közvetett következményei voltak? A beszerzett fegyverek egyéb szereplők általi használatának korlátozására történtek-e lépések, ezek mennyiben tekinthetők hatékonynak?

\section{Szaúd-Arábia és az Emirátusok jemeni részvétele}

A jemeni konfliktus azon szakaszától kezdve, ahonnan egyértelműen megfigyelhető külső felek beavatkozása a harcokba, Szaúd-Arábia és szorosabb térségbeli szövetségesei jelentős számú és komoly harcértékkel bíró egységeket vetettek be. Mint a jemeni kormányerőket támogató koalíciós erők vezetője, Szaúd-Arábia haderejének valamennyi haderőnemével részt vesz (vagy részt vett korábban) a hadműveletekben. A szaúdi haderő fegyverbeszerzéseit, a különböző képességek kialakítását szinte teljes egészében az Iráni Iszlám Köztársasággal (Irán) való szembenállás határozza meg. Ez azt jelenti, hogy a haderőnemek elvárt képességeit egy esetleges Irán elleni fegyveres konfliktus leendő követelményeihez igazítják, ${ }^{7}$ ez a meghatározottság jelöli ki

„Koalíció" alatt a 2015 márciusában Szaúd-Arábia által vezetett államok (Szaúd-Arábia és további nyolc arab állam - Egyesült Arab Emirátusok, Egyiptom, Marokkó, Jordánia, Szudán, Kuvait, Katar és Bahrein - továbbá logisztikai támogatás formájában az Egyesült Államok) által megvalósított katonai intervencióban részt vevő országokat értem a tanulmány további részében.

6 Peter D. Wezemann: Saudi Arabia, armaments and conflict in the Middle East. Stockholm International Peace Research Institute-SIPRI, 2018. december 14.

7 Király István Mihály: Szaúd-Arábia és Irán katonai képességeinek, védelmi iparának és védelmi költségvetésének összehasonlító elemzése. Nemzet és Biztonság, 11. (2018), 1. 108-112. 
az egyes fegyverbeszerzések irányát és kereteit. ${ }^{8}$ Ennek megfelelően a szaúdi haderö ${ }^{9}$ sokkal inkább egy nagyméretű, konvencionális háborúra van felkészítve, mint egy aszimmetrikus - jellegében proxyháborúra emlékeztető - konfliktus megvívására. ${ }^{10}$ A királyság fegyvervásárlásai európai szemmel szinte felfoghatatlan méretekben zajlanak, tulajdonképpen az elmúlt tíz évben folyamatosan a világ első tíz állama között volt e tekintetben. ${ }^{11}$ A beszerzett eszközök és fegyverrendszerek az esetek döntő részében nem pusztán mennyiségükben, de minőségükben is kimagaslóak, ezt jól jelzi a fegyverek származási hely szerinti csoportosítása is ${ }^{12}$ (többségük az USA, illetve néhány más hagyományos fegyverexportőr államból származik). ${ }^{13}$

Az Emirátusok szintén a legnagyobb ütemben fegyverkező közel-keleti államok közé tartozik, mind az általános gazdasági teljesítményéhez, mind az egy före eső GDP-hez viszonyított arányt tekintve. Fegyverbeszerzések terén az államalakulat egyértelműen a legfejlettebb, technikai, müszaki szempontból élvonalbeli eszközöket preferálja. Elsősorban az Egyesült Államokból, illetve a legnagyobb európai fegyvergyártóktól (francia, német, olasz) szerzi be eszközeit.14 Szaúd-Arábiához hasonlóan elmondható, hogy nagy számban és - sok esetben - adott feladatra egyszerre több, párhuzamosan alkalmazható fegyverrendszert is beszerez (ennek persze logisztikai szempontból sokszor inkább hátrányai vannak, mint előnyei). Összességében egy technikailag rendkívül fejlett, lakosságához képest jelentős számú, sokféle feladatra bevethető haderővel rendelkezik, amely az ország méretéhez képest jóval nagyobb katonai erőt képvisel. ${ }^{15}$

\section{Koalíciós fegyverrendszerek, haderőnemenként}

Az alábbiakban következő áttekintő elemzés mindenekelőtt a térség legnagyobb országai között szereplö, egyben a legnagyobb katonai potenciállal rendelkező koalíciós résztvevők, Szaúd-Arábia és az Egyesült Arab Emirátusok fegyverrendszereire koncentrál, mégpedig haderőnemenként elkülöníthető megoszlás szerint.

\footnotetext{
Király (2018): i. m.

A A szaúdi haderő önkéntes, professzioniális szerveződésü, bár időről időre felmerül az országban a sorkötelezettség bevezetésének ötlete.

10 Ben Brimelow: Saudi Arabia has the best military equipment money can buy - but it's still not a threat to Iran. Business Insider, 2017. december 16.

11 A Stockholmi Békekutató Intézet (SIPRI) adatai szerint Szaúd-Arábia 2014-2018. között a világ legnagyobb hagyományos fegyvervásárlója volt. Az IHS Jane's szakmai kiadványai szerint pedig fegyverimport tekintetében is folyamatosan az első három állam között volt az elmúlt évtizedben.

12 USA and France dramatically increase major arms exports; Saudi Arabia is largest arms importer, says SIPRI. Stockholm International Peace Research Institute - SIPRI, 2020. március 9.

13 Helen Davidson - Christopher Knaus: Australian weapons shipped to Saudi and UAE as war rages in Yemen. The Guardian, 2019. július 25.

14 Dan Sabbagh: Don't let Saudi arms ship dock in UK, say campaigners. The Guardian, 2020. február 5.

15 Pieter D. Wezeman et al.: Trends in International Arms Transfers, 2018. Stockholm International Peace Research Institute-SIPRI, 2019. 11-12.
} 


\subsection{Szaúd-Arábia}

Szaúd-Arábia saját védelmi ipar létrehozására irányuló határozott törekvései ellenére fegyverei jelentős részét, a korábbi ilyen típusú gyakorlatát továbbra is követve, mind a mai napig külföldi forrásból szerzi be. Hadi importja az Egyesült Államok és Franciaország mellett többek között Latin-Amerikából is érkezik (Brazília).

\subsubsection{Szárazföldi haderönem}

A szárazföldi haderőnem legfontosabb fegyverrendszerei, amelyeket a jemeni hadszíntéren vagy a szaúdi-jemeni határon alkalmazott a sivatagi királyság:

- M1A2 Abrams harckocsi: Az amerikai szárazföldi erők fő harckocsijának számító fegyver nagy számban áll rendelkezésre a szaúdi hadseregben, ez képezi a páncélos alakulatok gerincét. ${ }^{16} \mathrm{~A}$ típus már viszonylag régi alapfejlesztés eredménye, de még mindig kifejezetten modern és ütőképes eszköznek számít kategóriájában. ${ }^{17}$ Viszonylagos költségessége miatt jellemzően csak a komoly pénzügyi háttérrel rendelkező, nagy haderők engedhetik meg maguknak a beszerzését. Az Abrams harckocsik Jemenben megtörtént bevetéséről ellentmondásos információk lelhetők fel, bizonyos források megerősitették ennek tényét, és kétes eredményekről számolnak be..$^{18}$ Amit a szaúdi források is megerősítenek, az a harckocsi-alakulatoknak a szaúdi-jemeni határra történő felvonultatása, illetve tartósan a térségben állomásoztatás ${ }^{19}$ a jemeni ellenzéki erők esetleges határ menti támadásainak elhárítása céljából. ${ }^{20}$

- AMX 30 harckocsi: A francia AMX vállalat által gyártott harckocsi néhány generációval korábbi konstrukció, és jelentős mennyiséggel rendelkezik belőle a szaúdi haderő (továbbá a koalíció másik fontos hatalma, az Egyesült Arab Emirátusok is). A hadműveletek kezdetén ez a modell nem lépte át a szaúdijemeni határt, határvédelmi feladatokra vetették be, a későbbi időszakban azonban több olyan kép is napvilágot látott, amelyek tanúsága szerint jemeni területen látnak el feladatokat, szintén védelmi jelleggel. ${ }^{21}$

- M60A3 Patton harckocsi: Szintén korábbi időszakból, még az 1960-as évekből származó amerikai harckocsifajta, amely nagy számban áll hadrendben a királyságban. Utóbbi két típus képviseli a szárazföldi páncélos erők régebbi generációs, másodvonalbeli tömegét, míg a fejlett technikát egyértelműen

\footnotetext{
A páncélos erők több, mint $40 \%$-át alkotja a típus.

Defence Security Cooperation Agency: Kingdom of Saudi Arabia - M1A2S Saudi Abrams Main Battle Tanks and M88Al/ A2 Heavy Equipment Recovery Combat Utility Lift Evacuation System (HERCULES) Armored Recovery Vehicles (ARV) (2016. augusztus 9.)

18 Elsősorban jemeni ellenzéki források hoztak nyilvánosságra olyan videófelvételeket, amelyeken páncéltörő eszközöket sikerrel vetnek be a harckocsi ellen.

19 Direction de Renseignement Militaire: Yémen - Situation sécuritaire. Paris, (2018. szeptember 25.).

20 Marcus Weisgerber: Saudi losses in Yemen war exposed by US tank deal. Defense One, 2016. augusztus 9.

21 Direction de Renseignement Militaire (2018): i. m. 8.
} 
az Abrams tank jelenti. A fenti típusokhoz hasonlóan a szaúdi-jemeni határon állomásozott, területvédelmi jelleggel..$^{22}$

- Nexter Aravis: A francia páncélozott szállító járművet bevetették a Jemenben harcoló erők kötelékében. ${ }^{23}$

- M113 páncélozott csapatszállító jármü: Az amerikai jármüvet szintén bevetették Jemenben, elsősorban az ország északi, határ menti részein folyó műveletek során. ${ }^{24}$

- M109 Paladin önjáró tüzérségi eszköz: Az amerikai eszközt Jemenben nem, de a szaúdi-jemeni határon már a konfliktus kezdetétől bevetették, egyrészt határvédelmi feladatokra, másrészt a határról kiinduló, jemeni területen lévő célpontok ellen irányuló múveletek tüzérségi támogatása során. ${ }^{25}$ Felhasználásával számos alkalommal került sor szaúdi tüzérségi csapásra jemeni célpontok ellen, amelyek között több meglehetősen kétes eredményű eset is akadt, ${ }^{26}$ jelentős járulékos veszteséggel. ${ }^{27}$

- Caesarhordozható $155 \mathrm{~mm}$-es löveg: A francia gyártó típusát kerekes platformon telepítették, elsősorban a szaúdi-jemeni határvidéken, illetve egyes jelentések szerint Jemen északi területein is bevetették. ${ }^{28}$

- Astros // sorozatvető: A brazil Avibras vállalat rakétás tüzérségi járművét a fentiekhez hasonlóan szintén a két ország határán vetették be, a határon átnyúló rakétacsapásokat hajtottak végre vele jemeni célpontok ellen. ${ }^{29}$

\subsubsection{Légierö}

Szaúd-Arábia légi haderőnemének legjelentősebb eszközei, amelyek különböző módon érintettek voltak a jemeni műveletekben:

- F-15S/SA: A szaúdi légierő fő csapásmérő erejét képező amerikai Boeing F-15-ös vadászbombázó beszerzése két szakaszban történt, a legutóbbi „csomagban” a jelenleg elérhető legfejlettebb konfigurációban. ${ }^{30} \mathrm{~A}$ repülőgép a műveletek kezdetétől aktívan részt vett a harci cselekményekben, elsősorban a szárazföldi alakulatok közeli légi támogatásában (close air support), ${ }^{31}$ valamint bombázó

\footnotetext{
Direction de Renseignement Militaire (2018): i. m. 8.

Direction de Renseignement Militaire (2018): i. m. 8.

Direction de Renseignement Militaire (2018): i. m. 8.

Direction de Renseignement Militaire (2018): i. m. 8.

2019. december 24-én egy nagy publicitást kapott tüzérségi támadásban 17 civil lakos vesztette életét egy jemeni településen, Saada kormányzóságban, a szaúdi-jemeni határhoz közel.

27 Saudi-led coalition's artillery shelling kills 17 in Yemen. People's Dispatch, (2019. december 27.).

28 Direction de Renseignement Militaire (2018): i. m. 8.

29 Direction de Renseignement Militaire (2018): i. m. 9.

30 A legutóbbi új gépek beszerzésével párhuzamosan a korábbi F-15-ös vadászbombázók új típussal (F-15SA) megegyező szintre történő fejlesztéséröl is megrendelés született.

31 Az ún. close air support, vagy közeli légi támogatás lényege, hogy a szárazföldi alakulatok harcát - sok esetben - a saját erők közvetlen közelében lévő ellenséges erők ellen rendkívül pontosan végrehajtott légicsapásokkal támogassák. Alkalmazása komoly technikai felkészültséget, gyakorlottságot, valamint a szárazföldi és légi egységek közötti öszszehangolt együttmüködést, kommunikációt követel meg. A nyugati haderők utóbbi két évtizedben rendkívül magas szintre fejlesztették a képességet, elsősorban a különböző aszimmetrikus jellegü konfliktusok során.
} 
feladatkörben. ${ }^{32}$ Bevetésüket heves kritika érte, a fentebb említett magas járulékos veszteségek sokszor e típus alkalmazásához kapcsolódtak. A jelenség különösen azért váltott ki kritikát a szakértők körében is, mert e géptípus más országok légierejének alkalmazásában, más konfliktusokban éppen arról vált híressé, hogy a korábbi időszakhoz képest sokkal pontosabb csapásmérésre alkalmas, minimalizálva vagy elkerülve ezzel a civil áldozatokat. ${ }^{33} \mathrm{~A}$ fegyver eladásával az amerikai fél nem pusztán magát az eszközt, hanem széles körü kiképzési programot is kínált, amerikai légi bázisokon oldva meg a leendő szaúdi pilóták felkészítését és a modern légicsapások módszertanának átadását. ${ }^{34}$ Mindezek ellenére rendkívül nagy volt a civil áldozatok száma a repülőgép által végrehajtott bevetések során, ${ }^{35}$ mégpedig utólagos értékelések szerint elsősorban a bevetések tervezésének és végrehajtásának hiányosságai okán. ${ }^{36}$

- EF-2000 (Eurofighter) Typhoon: Az európai Airbus konzorcium által gyártott 4. generációs vadászbombázó szintén nagy mennyiségben áll rendelkezésre a sivatagi királyság légiereje számára. A gépeket a jelentések szerint szigorúan szaúdi bázisokról üzemeltetve intenzíven használták is valamennyi olyan jemeni hadszíntéren, ahol légicsapásokra került sor: részben bombavető feladatkört láttak el, részben pedig a légtérben tevékenykedő egyéb koalíciós repülőgépek vadászfedezeteként szolgáltak. ${ }^{37}$

- Tornado IDS: Az európai légierőkből lassan kivonásra kerülő, közös európai fejlesztésü, 3. generációs vadászbombázó- és felderítő típust szintén gyakran alkalmazták a konfliktus során, mindenekelőtt bombázó funkcióban. ${ }^{38}$ A repülőgép - életkora ellenére - alkalmas precíziós csapásmérésre és pontos felderítésre, akár 4. és 4+ generációs vadászgépekkel együttmúködésben is (erre jó példát szolgáltattak a Brit Királyi Légierő azonos típussal végrehajtott 2011-es líbiai, majd 2014-től szíriai bevetései). Ennek fényében szintén meglepőek a nagy járulékos veszteségekkel járó szaúdi bevetési eredmények Jemenben.

- Damoclès lézeres célmegjelölőkonténer: A fenti repülőgéptípusokhoz szervesen kapcsolódó, kiegészítő eszközről van szó, amely a precíziós csapásmérésben segíti a pilótákat. Az eszköz korábbi, 3. generációs fejlesztésnek számít ezen a téren, mégis nagymértékben elősegíti a pontosabb csapásmérést és a járulékos veszteségek elkerülését. ${ }^{39}$ A konténer jemeni alkalmazását több forrás is

32 Direction de Renseignement Militaire (2018): i. m. 7.

33 Jó példát jelent erre az amerikai és szövetséges nyugat-európai légierök által Szíriában és Irakban 2014-töl kezdve végrehajtott precíziós csapásmérő bevetések tömege, amelyeket viszonylag alacsony járulékos veszteségek mellett hajtottak végre.

34 Pl. az arizonai Luke Légibázison települő kiképzőszázad kötelékében.

35 Pl. 2015. októberében Haidan településen az Orvosok Határok Nélkül (MSF) szervezet által üzemeltett kórházat érte súlyos légicsapás; 2016-ban a Hajjah kormányzóságban található piacot ért bombatámadás több mint 100 halálos áldozatot követelve; 2020. február 15-én pedig az Al-Jawf kormányzóságban ölt meg 31 civilt a koalíció légicsapása.

36 Mark Townsend: British target training os Saudi air force 'did not stop Yemen atrocities. The Guardian, 2019. június 23.

37 Direction de Renseignement Militaire (2018): i. m. 7.

38 Direction de Renseignement Militaire (2018): i. m. 7.

39 Az eszköz kifejlesztésére eredetileg megbízást adó és azt műveleti környezetben is alkalmazó Francia Légierő számos hadszíntéren vetette be a konténert. Tény ugyanakkor, hogy az eszköz hiányosságait kiküszöbölendő, már tesztelés és rendszeresítés alatt áll az utódtípus, a Thalios konténer. 
megerősítette, amely tény ismételten felveti az elvárt csapásmérési pontosság hiányának kérdését. ${ }^{40}$

- AH-64E Apache Guardian: A szaúdi haderő egyik legújabb típusa, az amerikai Boeing vállalattól nemrégiben beszerzett Apache Guardian, ${ }^{41}$ a rendkívül sikeres harci helikopterfajta legújabb verziója. A típust viszonylagosan magas ára miatt egyelöre még kevés haderő kezdte el rendszeresíteni, ám az a jelenleg elérhető támadó helikopterek vitathatatlanul legfejlettebb képviselője. Elsődlegesen szaúdi légibázisokról, illetve jemeni előretolt bázisokról kiindulva vetették be a jemeni lázadó erők ellen. ${ }^{42}$

- UH-60M Black Hawk szállítóhelikopter: A szintén amerikai, és a közepes méretü szállító helikopter típusához tartozó eszköz kulcsfontosságú szerepet játszott a szaúdi és a koalíciós katonák hadszíntéren történő szállításában. Több szaúdi és - egyes jelentések szerint - jemeni bázisról is üzemelt a típus. ${ }^{43}$ Esetében szintén történt gépveszteség, köszönhetően annak, hogy a lázadó erők bőségesen rendelkeztek úgynevezett manpads ${ }^{44}$ kategóriájú légvédelmi eszközökkel. Utóbbiak különösen veszélyesek a csapatszállító légi eszközökre, elsősorban közepes vagy alacsony magasságon. Ilyen profilú bevetésre pedig a harcok jellegéből adódóan sok esetben került sor a jemeni hadszíntéren, a viszonylag kis létszámú csapatok gyors mozgatását és támogatását kívánó műveletek során.

- AS-532 Cougar szállitóhelikopter: A francia fejlesztésü helikopter a fentebb leírt amerikai UH-60M típushoz teljesen hasonló szerepkörben vett részt a hadműveletekben. A típust kizárólag szaúdi bázisokról kiindulóan vetették be, ${ }^{45}$ több esetben a szaúdi és koalíciós különleges alakulatok tagjait szállították vele egy-egy kiemelt jelentőségü célponthoz. ${ }^{46}$

- Saab 2000 Erieye: A nemzetközi piacon elérhető úgynevezett korai elörejelző és légtérellenőrző, speciális rendeltetésű repülőgépek közül a Szaúdi Légierő a svéd fejlesztést választotta, amely jelentős részt vállalt a jemeni hadmüveletekben. ${ }^{47}$ Mint napjaink szinte valamennyi légi manőverében, ez esetben is kulcsfontosságú a légtérellenőrzés, a repülőeszközök megfelelő pontosságú célravezetése, a légi helyzetkép folyamatos nyomon követése. A jemeni légtér meglehetősen „sürü", a nagyszámú koalíciós repülőgép megfelelő irányítása, a lehetséges földi célpontok azonosítása és a csapásmérések vezetése kulcsfontosságú. A légi hadmüveletek irányítása és különösen a csapásmérések

40 Direction de Renseignement Militaire (2018): i. m. 7.

41 A jemeni huti lázadók és különböző paramilitáris erők több féle páncélozott szállító és harcjárművel rendelkeznek, melyek ellen többször is bevetést hajtottak végre a szaúdi Apache helikopterek. Érdekesség, hogy az óriási technikai különbségek ellenére gépveszteséget is elszenvedett a királyság hadereje, bizonyos esetekben több haderőnem bevonását érintő mentőakciókra kényszerítve őket a lelőtt gépek pilótáinak kimentése érdekében, illetve a technika ellenséges kézre kerülésének megakadályozására.

42 Direction de Renseignement Militaire (2018): i. m. 7.

43 Direction de Renseignement Militaire (2018): i. m. 7.

44 Man-portable air-defense system, vagyis ember által hordozható, vállról indítható légvédelmi rakéta.

45 Direction de Renseignement Militaire (2018): i. m. 7.

46 Sajtóhírek szerint a müveletek kezdeti szakaszában, 2015-ben több alkalommal is szokatlan, területvédelmi célokra vetették be a szaúdi különleges alakulatok katonáit, nevezetesen a szaúdi-jemeni határ kiemelt pontjait kellett védeniük, esetleges jemeni ellentámadásra készülve vagy ellenséges rakétatámadás kiinduló pontjainak lokalizálása céljából.

47 Direction de Renseignement Militaire (2018): i. m. 7. 
pontossága okán sok kritika érte a szaúdi légierő ezen komponensét is, egyes vélemények szerint a bevetett légtérellenőrző repülőgépek száma egyszerüen elégtelen volt, és a szükséges harceljárások terén sem rendelkezett elegendő tapasztalattal az üzemeltető. ${ }^{48}$

\subsubsection{Haditengerészet}

A koalíciós erők haditengerészeti jelenléte is igen aktív volt a konfliktus során. A vízi haderőnem elsősorban a jemeni lázadók fegyverrel és felszereléssel történő ellátását megakadályozni hivatott tengeri blokád kialakításában és fenntartásában vett részt. ${ }^{49} \mathrm{~A}$ műveletet Szaúd-Arábia kezdeményezte és indította el, de méretéhez képest az Emirátusok is komoly részt vállalt annak megvalósításából. ${ }^{50} \mathrm{~A}$ blokád azonban eredeti célját nem érte el teljes mértékben, lévén a jemeni lázadó erők egyik fő támogatójának számító Irán képes volt más útvonalakon biztosítani a fegyverutánpótlást. ${ }^{51}$ Az ennek során bevetett eszközök:

Al-Madinah osztályú fregatt: A francia hajógyárakban (CNIM) készült fregattokból Szaúd-Arábia az 1980-as években szerzett be négyet. A fedélzeti helikopterekkel is rendelkező hajóosztály darabjait elsősorban a blokád fenntartására használták a jemeni partok mentén. ${ }^{52}$

Mekka osztályú fregatt: A szintén francia gyártású hajóosztályból három darab készült a szaúdi haditengerészeti erők részére a 2000-es évek első felében. Az átadásukkor kifejezetten fejlett, modern technikai megoldásokkal rendelkező hajókat a királyság hadvezetése a fentiekben bemutatott eszközökhöz hasonlóan a tengeri blokád fenntartására, valamint a jemeni partok mentén, sekély, part menti vizeken végrehajtott müveletekben használta. ${ }^{53}$ Kialakítása erre tökéletesen alkalmassá tette, több hadmozdulat során is a koalíciós különleges alakulatokat támogatta, illetve a tengerről biztosította a szárazföldi csapatok mozgását.

Al-Siddiq osztályú rakétás járőrhajó: Az amerikai építésü ${ }^{54}$ vízi harceszközök jelentős fegyverzettel rendelkeznek, aktívan ki is vették részüket a Jemen elleni tengeri blokád fenntartásából. ${ }^{55}$

48 Megjegyzendő, hogy - talán nem függetlenül a kritikáktól és a jemeni hadszíntéren mutatkozó hiányosságoktól - a szaúdi vezetés már megkezdte egy újabb, nagyobb teljesítményủ és őrjáratozási idejű váltótípus vagy kiegészítő típus kiválasztásának és beszerzésének előkészítését.

49 A jemeni lázadó erők elszigetelését és fegyverutánpótlásának megakadályozását célzó művelet 2015-ben vette kezdetét, szaúdi hadihajók bevonásával; 2016-ban az USA is csatlakozott, míg 2017-től még szigorúbb keretek között folytatta a blokád fenntartását a koalíció.

50 James Ross: Yemen: Coalition blockade imperils civilians. UN should sanction senior Saudi leaders. Human Rights Watch, 2017. december 7 .

51 Jonathan Saul: Exclusive: Iran Revolutionary Guards find new route to arm Yemen. Reuters, 2017. augusztus 1.

52 Direction de Renseignement Militaire (2018): i. m. 9.

53 Direction de Renseignement Militaire (2018): i. m. 9.

54 A Peterson Builders hajógyár.

55 Direction de Renseignement Militaire (2018): i. m. 9. 


\subsection{Egyesült Arab Emirátusok}

A koalíció második legkomolyabb katonai erőt felvonultató tagja az Egyesült Arab Emirátusok. Szaúd-Arábiához hasonlóan ennek az országnak valamennyi haderőnemét érintették a hadműveletek, bár különböző mértékben. Az állam kis méretéhez képest jelentős hadsereggel rendelkezik és - nagy szomszédjához hasonlóan -jellemző módon a legfejlettebb nyugati haditechnikát alkalmazza. A jemeni hadműveletekből védelmi képességéhez és gazdasági erőforrásaihoz képest rendkívül nagy arányban vette ki részét. Az Emirátusok haderőnemeinek jemeni szerepvállalását a részvételük mértéke szerinti sorrendben tárgyaljuk az alábbiakban.

\subsubsection{Légierö}

Az Emirátusok saját nagyságához képest viszonylag jelentős számú, de a térség többi államához viszonyítva nem kiemelkedő mennyiségü katonai repülőgéppel rendelkezik, a légierő gépállománya azonban jó technikai felszereltségü, és magas szinten kiképzett személyzet működteti. Ennek a korszerü, ütőképes haderőnemnek jóformán minden egysége részt vett a harcokban legalább valamilyen szinten, komolyan hozzájárulva ezzel a koalíciós hadműveletek céljainak eléréséhez.

- Mirage 2000-9: A francia Dassault cég által gyártott többcélú vadászbombázót amely az alaptípus modernizált változata - az Emirátusok légiereje rendszeresen indította Jemenben elöre meghatározott, kiemelt célpontok ellen, ${ }^{56}$ valamint több esetben közeli légi támogatási feladatok elvégzésére is. ${ }^{57} \mathrm{Az}$ Emirátusok légierejének gerincét alkotó típus nagymértékben kivette részét a jemeni bevetésekből, szinte minden szóba jöhető feladatfajtát megoldottak a géppel, mégpedig - a koalíciót támogató nyugati légierők képviselőinek megítélése szerint - sokkal magasabb fokú hatékonysággal, mint a jóval nagyobb szaúdi légierő. ${ }^{58}$

- F-16 C/D: A rendkívül elterjedt amerikai vadászbombázó Block 60-as verzióját szintén széles körben vetette be a légierő, mind vadászbombázó szerepkörben, mind pedig vadász kísérő szerepben olyan alkalmakkor, amikor más gépeket (például Mirage 2000-9-est vagy éppen szaúdi Tornado IDS-t) támogattak. E típust is alapvetően hazai vagy szaúdi előretolt légi bázisokon állomásoztatták, de volt példa Jemenben létesített átmeneti légi bázisok használatára is. ${ }^{59}$

- Damoclès lézeres célmegjelölö konténer: A szaúdi légieröhöz hasonlóan az Emirátusok vadászpilótái is használták az eszközt, mindenekelőtt Mirage 2000-9-es típusú gépeiken. ${ }^{60}$ Érdekes tapasztalat, hogy a szaúdi gépekkel ellentétben az Emirátusok gépei jóval nagyobb mértékủ pontosságot értek el az eszköz használatakor a légicsapások során. A sokkal nagyobb gyakorlati

\footnotetext{
Például a lázadó erök olyan közép- vagy felső szintű harctéri parancsnokai elleni célzott bevetések során, akik hollétéről előzetesen sikerült hiteles információkat szerezniük.

Direction de Renseignement Militaire (2018): i. m. 10.

58 Michael Knights: Lessons from the UAE war in Yemen. Lawfare, 2019. augusztus 18.

59 Knights (2019): i. m.

60 Knights (2019): i. m.
} 
jártasságot igénylö közeli légi támogatási feladatokat is legtöbbször e típus (Mirage) és a célzó konténer (Damoclès) kombinációjával hajtották végre. Ennélfogva ezek a bevetések kisebb járulékos veszteségeket is eredményeztek.

- AT-802: Az eredetileg mezőgazdasági célokra használt amerikai gép könnyűfegyverzettel felszerelt támadó változatáról van szó, ${ }^{61}$ amelyet csekélyebb intenzitású, aszimmetrikus jellegú légi hadműveletekhez fejlesztettek ki. A gépet a szárazföldi alakulatok ellen kis magasságból végrehajtott támadásokhoz használták, jemeni területen létesített előretolt bázisokról, nagy sikerrel. ${ }^{62}$ A típus hatékonyabban és olcsóbban üzemeltethető ilyen célpontok ellen, mint nagyobb, sugárhajtású társai.

- AH-64E Apache Guardian: A rendkívül fejlett támadó helikoptert - hasonlóan a szaúdi légierőben alkalmazott típustársához - rendszeresen bevetették, jemeni repülöterekre és bázisokra települve. ${ }^{63}$

- UH-60M Black Hawk: A szintén amerikai szállítóhelikopter elsősorban szárazföldi különleges alakulatokat szállított jemeni célpontokhoz, az azonos szaúdi típussal megegyező bevetési profillal. ${ }^{64}$

- CH-47F Chinook: Az amerikai fejlesztésü, ${ }^{65}$ közepes szállítóhelikopter a típus legfejlettebb verziója, amely világszerte több légierőben is megtalálható. Számos bevetésen vett részt, a fentiekhez hasonlóan előretolt jemeni, illetve szaúdi bázisokról kiindulva. ${ }^{66} \mathrm{~A}$ típus rendkívül sikeres az összes olyan hadszíntéren, ahol bevetették, így Jemenben is igen nagy hasznát látták a koalíció katonái.

- A330 MRTT: Az Airbus konzorcium által gyártott fejlett légi utántöltő repülőgép kulcsfontosságú bevetéseket teljesített mind Jemen felett, mind a környező országok légterében. Elsősorban a bevetésre induló vagy onnan visszaérkező vadászbombázók és vadászrepülőgépek légi utántöltésében segitett. ${ }^{67}$ Ez a képesség - mint minden napjainkban zajló légi művelet esetében - elengedhetetlen előfeltétele a bevetett repülőgépek zavartalan ténykedésének és a műveletek sikerének. Hasonlóan más légi műveletekhez (mint amilyenek az Iszlám Állam elleni műveletek is voltak Szíriában és Irakban 2014-től kezdődően), a légi utántöltő gépek hiánypótló eszközök, és általában kevés áll rendelkezésre belőlük, emiatt az Emirátusok ezen hozzájárulása véleményem szerint az állam puszta számarányai alapján elvárhatónál sokkal nagyobb mértékben segítette a koalíció céljainak elérését.

- Patriot PAC 3 légvédelmi rakétarendszer: A jelenleg elérhető egyik legfejlettebb, amerikai gyártású, közepes hatótávolságú légvédelmi rakétát nagy számban telepítették a legfontosabb szaúd-arábiai és jemeni elöretolt bázisokra és repülőterekre csakúgy, mint vezetési harcálláspontokra. ${ }^{68} \mathrm{~A}$ Patriot-ütegek nagy részét - bár azokkal Szaúd-Arábia is rendelkezik - az Emirátusok bocsátotta

\footnotetext{
Gyártója az Air Tractor Inc. vállalat.

Direction de Renseignement Militaire (2018): i. m. 10.

Direction de Renseignement Militaire (2018): i. m. 10.

Direction de Renseignement Militaire (2018): i. m. 10.

Gyártója a Boeing vállalat.

Direction de Renseignement Militaire (2018): i. m. 10.

Direction de Renseignement Militaire (2018): i. m. 10.

Direction de Renseignement Militaire (2018): i. m. 10.
} 
a hadművelet rendelkezésére (nagy valószínűséggel ezzel tehermentesítve a szaúdi ütegeket, lehetővé téve azok hazai objektumok védelmében történő hatékonyabb részvételét) ${ }^{69}$

- Pantsir S-1:70 Az orosz fejlesztésü önjáró légvédelmi harcjármüvet szintén bevetették a Jemenben harcoló koalíciós alakulatok védelmében. ${ }^{71} \mathrm{Az}$ eszköz a koalíciós hatalmak által használt kevés nem nyugati eredetü fegyver közé tartozik. Ugyanakkor a tapasztalatok szerint hatékonyan képes ellátni feladatát hadmüveleti területen is. ${ }^{72}$

\subsubsection{Szárazföldi haderönem}

A jemeni konfliktusban katonai erejéhez és erőforrásaihoz képest nagy erőkkel részt vevő Emirátusok szárazföldi haderőneme az ország méretéből és a követett katonai doktrínából adódóan nem nagy volumenü, ennélfogva Jemenben is csupán viszonylag kis létszámú alakulattal és technikai eszközzel képviseltette magát:

Leclerc harckocsi: A francia gyártású, ${ }^{73}$ fejlett technikát képviselő harckocsik a jemeni harcokban jelentések szerint közvetlenül nem vettek részt, elsősorban a határ mentén állomásoztatták őket, segítséget nyújtva a szaúdi erők számára. ${ }^{74}$ Szükség esetén kis mélységben hatoltak be Jemen területére. ${ }^{75}$

\subsubsection{Haditengerészet}

Legfőképpen a tengeri blokád fenntartásában, járőrfeladatok végrehajtásában, esetenként különleges alakulatok szállításában és bevetésében vettek részt:

- Baynunah osztályú rakétás korvett: A francia cég által előállított ${ }^{76}$ korvettek az Emirátusok legújabb hajóegységei közé tartoznak, összesen 6 db-ot vett át a haditengerészet. A jemeni konfliktushoz kapcsolódóan valamennyit bevetették, ${ }^{77}$ egyrészt a hagyományos feladatköreik közé tartozó járörtevékenység, másrészt a jemeni part közeli hadműveletekben való részvétel formájában. (Itt különleges alakulatokat tettek partra, illetve helikopteres bevetéseket repültek.)

69 Erre a hadműveletek előrehaladtával egyre nagyobb szükség is mutatkozott, figyelembe véve a megszaporodó sikeres jemeni rakétatámadásokat több szaúdi katonai és civil, ipari célpont ellen.

70 NATO kódja SA-22 Greyhound.

11 Direction de Renseignement Militaire (2018): i. m. 10.

72 A fegyvert a jelentések szerint az orosz csapatok is bevetették a szíriai harcok során a szövetséges, szír szárazföldi alakulatok védelmére, 2015-töl kezdődően.

73 Gyártója a korábbi francia GIAT vállalat (napjainkban már Nexter).

74 Érdekesség, hogy az Emirátusok nem a Franciaországban eredetileg rendszeresített lőszert alkalmazza, hanem elsősorban különböző kínai lőszertípusokat integrált a típushoz.

75 Direction de Renseignement Militaire (2018): i. m. 10.

76 Gyártója a Constructions Mécaniques de Normandie vállalat (illetve a későbbi példányok esetében már az Abu Dhabi Ship Building Company).

77 Direction de Renseignement Militaire (2018): i. m. 11. 
- Muray-jib osztályú korvett: A német gyártású78 hajóegységeket még az 1990-es években szerezte be az Emirátusok. Tekintettel a típus helikopterhordozó képességére, e hajóosztály tagjai is aktívan kivették részüket a blokád fenntartásából, ${ }^{79}$ illetve többször is part menti hadműveleteket hajtottak végre.

- Ghannatha osztály: A svéd gyártó által készített ${ }^{80}$ és a közelmúltban (2015-ben) átadott rakétás hajók elsősorban a koalíció kiinduló kikötői és Jemen keleti partvidéke közötti logisztikai feladatok biztosításában vettek részt. ${ }^{81}$

- Murjan osztályú aknamentesítő hajó: Az eredetileg a német haditengerészet kötelékébe tartozó hajókat 2006-ban adták át az Emirátusok tengeri haderőneme számára. 2017 júliusában visszavonták az éles bevetésekről, ${ }^{82}$ a hajóosztály egy tagja ellen elkövetett sikeres - robbanóanyaggal felszerelt - motorcsónakos támadást követően.

- Al-Quwaisat osztályú partraszálló hajó:83 Több jemeni, part menti műveletben részt vett, ${ }^{84}$ elsősorban az Emirátusok szárazföldi alakulatainak partra szállításában vetették be.

- Al-Shareeah osztály és Al-Jinahan osztály: A logisztikai támogató hajók egy közel-keleti hajóépítő konglomerátum mühelyeiben készültek, ${ }^{85}$ ezzel a ritka „,hazai” katonai eszközök közé tartoznak a térségben. Intenzíven használták őket a műveletek során, ${ }^{86}$ természetesen elsősorban különböző szállító, logisztikai műveletekben.

- S100 Camcopter:87 A z osztrák gyártmányú, pilóta nélküli felderítő helikopter haditengerészeti felderítést végzett több féle jemeni müveletben is, ${ }^{88}$ a fentiekben részletezett al-Quwaisat osztály hajóin többször is felhasználták, elsősorban part menti, sekély vízi müveletekben.

\section{A fegyverek és alkalmazásuk}

A fentiekben röviden vázolt, Szaúd-Arábia és az Emirátusok által Jemenben alkalmazott fegyverrendszerek döntően nyugati - európai és amerikai - forrásokból származnak, elsősorban NATO-tagállamok fegyvergyártó vállalatainak termékei. Ez a nyilvánvaló nyugati exportsikerek formájában jelentkező szakmai, politikai befolyáson túl azt is jelenti, hogy e fegyverekhez használt lőszerek, muníció mind a NATO-ban rendszeresített szabványokat kell, hogy kövesse. Tehát egyfajta utánpótlási kötelezettséget és kényszerpályát is képvisel, vagyis például egy potenciális jövőbeni fegyverembargó

\footnotetext{
Gyártója a Lürssen vállalat.

Direction de Renseignement Militaire (2018): i. m. 10.

Gyártója a Swede Ship Marine vállalat.

Direction de Renseignement Militaire (2018): i. m. 10.

Direction de Renseignement Militaire (2018): i. m. 10.

Gyártója a maláj Piasau Slipways vállalat.

Direction de Renseignement Militaire (2018): i. m. 10.

A dubai illetékességű Focus Marine vállalat.

Direction de Renseignement Militaire (2018): i. m. 10.

Gyártója a Schiebel vállalat.

Direction de Renseignement Militaire (2018): i. m. 10.
} 
esetén sokkal nehezebb lenne alternatív beszállítók (például Kína, Oroszország) segítségével kiváltani ezen forrásokat. ${ }^{89}$

A harcoló alakulatok gerincét adó Szaúd-Arábia - a fenti tételes összefoglalóból is látható módon - erősen támaszkodott a különböző nyugati fegyverfajtákra. A légi múveletekben teljes egészében amerikai és európai típusokat alkalmazott (a csapásmérő bevetések esetén az F15-ös és a Tornado-gépeket), míg a határvédelmi és szárazföldi műveleteket amerikai és francia eredetű páncélos erőkkel hajtották végre. A nyugati technikai háttér a haditengerészeti műveletek során szintén szembeötlő volt. Ugyanakkor e technikai eszközök és fegyverek alkalmazását illetően nagyon komoly kritikák érték a koalíció tagjait: elsősorban a pontosság terén (csapásmérések esetén), valamint a hatékonyság tekintetében: a határok hatékony lezárása a legpozitívabb értékelések szerint sem volt teljes, számos fegyverszállítmány és egyéb utánpótlás eljutott a lázadó erőkhöz, nem beszélve a több sikeres rakéta- ${ }^{90}$ vagy egyéb típusú támadásról ${ }^{91}$ szaúdi célpontok ellen. ${ }^{92}$ Ráadásul ezen eszközöket nem teljesen önállóan, egyedül kellett alkalmaznia a szaúdi és az emirátusi haderőnek, ugyanis közvetett bizonyítékok láttak napvilágot arra vonatkozóan is, hogy az amerikai légierő pilóta nélküli felderítő repülögépekkel segítette a szaúdi légierő egységeit, mindenekelőtt a közvetlen légi támogatáshoz elengedhetetlenül szükséges pontos célazonosítás és -megjelölés területén. ${ }^{93} \mathrm{~A}$ technikai segítségnyújtáson túl ez a szükséges harceljárás elsajátítását is jelentette, amely kiképzéssel és gyakorlati oktatással érhető el, ugyanakkor napjaink légi hadviselésének egyik legkomplexebb, sok gyakorlást igénylő múveletéről van szó. Az amerikai légierő ezzel szemben tagadta, hogy ilyen jellegü segítséget nyújtott volna a szaúdiaknak. Ahogy az amerikai középső parancsnokság (CENTCOM) szóvivője fogalmazott: „Az amerikai haderő nem nyújt ilyen jellegű támogatást a szaúdi vezetésü koalíciónak [...], a mi szerepünk a koalíció kapcsán pusztán tanácsadó jellegủ. Felderítési szolgáltatásokat és a bevált gyakorlatok megosztását nyújtjuk levegö-föld csapásmérés terén és a fegyveres konfliktusok joga kapcsán." 94

Az átadott fegyverek alkalmazásának hatékonysága és azok esetleges civil célpontok elleni bevetése nem pusztán az USA-ban vetett fel kérdéseket. A francia védelmi miniszter, Florence Parly egy 2018. januári rádióinterjúban tulajdonképpen kizárta annak lehetőségét, hogy a harcoló feleknek eladott francia fegyvereket civilek ellen vethették be. Ahogyan fogalmazott: „a közelmúltban nem történt olyan fegyvereladás, amely fegyvereket a jemeni hadszíntéren vethették volna be". ${ }^{55}$ Ugyanakkor a korábbiakban felsoroltakból is kiolvasható, hogy mind a szaúdi, mind az emirátusi haderő nagy számban

89 implications. Stockholm International Peace Research Institute - SIPRI, 2019. június 28.

90 Noah Browning: Houthi missile arsenal holds a key to future Yemen peace. Reuters, 2016. november 22.

91 Houthis launch air attacks on Saudi capital, The Guardian, (2020. március 30.).

92 Ezek közül legnagyobb nyilvánosságot a 2019. szeptember 14-i, a szaúdi állami olajvállalat (Saudi Aramco) olajfinomító létesítményei ellen Abqaiq-ban drónokkal végrehajtott támadás kapott; valamint a 2020. március 28-i ballisztikus rakétákkal végrehajtott támadás a szaúdi főváros, Rijád ellen.

93 A jemeni lázadók által ellenőrzött területen lelőtt amerikai MQ-9 Reaper drón lelövése azt jelzi, hogy esetlegesen lézeres célmegjelölésben, tehát közvetlenül a csapásméréshez szükséges tevékenységben is segítségére volt az amerikai légierö a szaúdi egységeknek.

94 Alex Emmons: Secret report reveals saudi incompetence and widespread use of U.S. weapons in Yemen. The Intercept, 2019. április 15.

95 Emmons (2019): i. m. 
alkalmaz francia fegyvereket, közöttük igen modern és nemrégiben leszállított is akad (akár a határvédelemben és jemeni célpontok ellen bevetett harckocsikról, akár például a vadászbombázókon alkalmazott lézeres célmegjelölő konténerekről beszélünk). Újabb reakció a francia fegyverek használatára a harcoló felek által, miszerint „tudomásunk szerint a koalíció tagjai számára elérhető francia fegyvereket főképp védelmi szerepkörben, jemeni területen kívül [...], nem a frontvonalakon vetik be, és nem tudunk olyan civil veszteségről, amelyet bizonyítottan francia fegyverek bevetése okozott volna". ${ }^{96}$ Egy francia titkosszolgálati jelentés ${ }^{97}$ azonban pontosan meghatározta, hogy a szaúdijemeni határon a konfliktus több szakaszában is állomásoztatott tüzérségi eszközök hatósugarában legalább 430 ezer fős nagyságrendü jemeni lakosság élt.

Bár a legtöbb információ a nyugati eszközökről szól, akadtak kivételek. A két ország légiereje által alkalmazott fegyverek között kínai gyártású Wing Loong pilóta nélküli repülőeszközök is megtalálhatók, amelyek szintén csapásmérő feladatokban vettek részt. Legalább egy konkrét eset szerepelt a sajtóban, amikor egy ilyen drónnal hajtottak végre célzott légicsapást a húti erők egyik vezetője, Saleh al-Samad ellen. ${ }^{98}$

\section{Következtetések}

A koalíció jemeni hadműveleteit értékelő források legtöbbje elsődlegesen a szaúdi és az emirátusi haderővel foglalkozik, ezen belül is legfőképpen Szaúd-Arábia kapcsán fogalmaz meg kritikát. Elsősorban a csapásmérések során mutatott pontatlanság jelentkezik mint súlyos hiányosság. Mind a közeli légi támogatás, mind az előre tervezett célok elleni csapásmérés esetén elégtelen a szaúdi pilóták eljárása, és ez a jelentések szerint alapvetően hozzájárul a nagymértékü járulékos veszteséghez. Mindez az egyértelmű technológiai fölény (korszerü vadászbombázók, lézeres célmegjelölő konténerek, célfelderítő drónok stb.) megléte ellenére tapasztalható. Ezenkívül a tengeri müveletekben - közelebbről a tengeri blokád fenntartásakor - is kevésbé hatékonyan vettek részt a szaúdi alakulatok, mint a jóval kisebb erőkkel rendelkező Emirátusok katonái. A harmadik, szárazföldi haderőnem terén is felemás eredményeket tud felmutatni a szaúdi haderő. A hadsereg (és rendkívül nagy erőkkel a Nemzeti Gárda is) komoly létszámban és nagy mennyiségü haditechnikai eszközzel hozott létre egy védelmi vonalat a szaúdi-jemeni szárazföldi határon. ${ }^{99}$ Ezek a csapatösszevonások azonban az eredeti, határvédelmi céloknak sem tudtak maradéktalanul eleget tenni, mivel a gyakorlatban rendkívül porózus maradt a szaúdi-jemeni határ, és több, szaúdi területen végrehajtott támadás is megtörténhetett, a megerősített határvédelmi intézkedések ellenére is. ${ }^{100}$

96 Emmons (2019): i. m.

97 A Francia Katonai Hírszerzés (DRM) 2018-ban készített egy átfogó, belső jelentést a Jemenben harcoló felek harceljárásairól, az általuk alkalmazott fegyverekről. A belső jelentés kiszivárgott és ezzel szokatlan betekintést nyújtott a jemeni folyamatokba.

98 Chen Chuanren - Chris Pocock: Saudi Arabia buying and building Chinese armed drones, Aviaton International News, 2017. április 12 .

99 Több mint 300 harckocsival és jelentős mennyiségű tüzérségi eszközzel vonultak fel a határon, elsősorban védelmi jelleggel, de ezen eszközök - különösen a nagy távolságú csapásokra képes tüzérségi eszközök - egyúttal a jemeni területen, mélységben végrehajtott csapásokat is szolgálták.

100 Max Fisher et al.: Did American missile defence fail in Saudi Arabia? The New York Times, 2017. december 4. 
A koalíciót kívülről, korlátozottan támogató nyugati haderők (például USA) megítélése szerint az Emirátusok összességében is magasabb színvonalú teljesítményt nyújtott mind a közvetlen légi támogatás, ${ }^{101}$ mind a haditengerészeti múveletek terén. ${ }^{102}$

Összességében tehát megállapítható, hogy a koalíciós haderőket ért kritikák nem elsősorban a szóban forgó harceszközök, fegyverek hiányosságainak tudhatók be, sokkal inkább azok alkalmazásában, a bevetett harceljárásokban rejlenek az okok. E problémák gyökere megítélésem szerint egyrészt a gyakorlat és tapasztalat hiányában (például lézeres célmegjelölő eszközök alkalmazása, a közeli légi támogatás kihívásai), másrészt viszont a koalíciós hadvezetés eltérő céljaiban és az ezen célokhoz rendelt megoldásokban keresendők. A tapasztalatok tehát azt mutatják, hogy egy alapvetően modern fegyverekkel, erős haderővel rendelkező katonai hatalom nem automatikusan az általunk, európaiak számára az utóbbi években "megszokott” harceljárásokat és a precíziós, lehető legkevesebb civil áldozattal járó megoldásokat preferálja a hadműveleti célok elérése érdekében. Sokkal inkább a széles körü, általános katonai célok megvalósítása kap prioritást (adott esetben kevésbé kifinomult módszerekkel), bár ezek elérését is hátráltathatják a fentiekben vázolt különböző hatékonysági problémák.

Végezetül fontos megvizsgálni, hogy a Jemenben alkalmazott fegyverek és eszközök esetlegesen eljuthattak-e más térségbeli szereplőkhöz az eredeti alkalmazókon kívül? Ez a kérdés minden hasonló művelet esetében meglehetősen kényes, mind katonai, mind politikai szempontból. Érthető okokból az érintett szereplők nem sok információt osztanak meg e témakörben, de néhány esetről van tudomásunk. Egy 2018-as amerikai helyszíni riport arról számolt be, hogy páncélozott csapatszállító járművek, kézifegyverek és egyéb fejlett, amerikai és európai eredetű technikák jutottak a koalíció jemeni szövetségeseinek számító frakciók, félkatonai szervezetek kezére. ${ }^{103}$ Már a konfliktus kezdetétől jellemző volt, hogy a koalíció két legerősebb tagja - Szaúd-Arábia és az Emirátusok - saját helyi szövetségesei részére rendszeresen adott át fegyvereket, ezzel (is) megvásárolva egy-egy fegyveres csoport hosszabb-rövidebb ideig tartó hűségét. Ez a gyakorlat azonban például olyan esetekhez is vezetett, mint amikor az AQAP ${ }^{104}$ szervezethez kötődő Abu Abbasz Brigádok ${ }^{105}$ úgynevezett Oshkosh ${ }^{106}$ páncélozott jármüvekhez jutott. ${ }^{107}$ Egy másik eset pedig arról számol be, hogy a súlyos harcok helyszínéül szolgáló Hodeidah városában több úgynevezett MRAP ${ }^{108}$ jármú állt egy ultrakonzervatív, szalafista csoport, az Alwiyat al Amalqa (Óriások Brigádja) telephelyén. A járműveken még az eredeti szállítójelzés is látható

101 Az amerikai légierő szerint az emirátus pilótái magas, közel NATO-színvonalon voltak képesek közeli légi támogatást nyújtani a szárazföldi alakulatoknak a csapásmérő műveletek során.

102 Dacára annak, hogy az Emirátusok egy viszonylag szerény méretű haditengerészettel rendelkezik, elsősorban part menti múveletekre szakosodott hajóegységekkel.

103 Egyes al-Káida szervezethez köthető csoportoknál, szalafista félkatonai szervezeteknél és helyi, városi szinten szerveződött irreguláris csoportoknál is találtak elsősorban amerikai fegyvereket.

104 Al-Káida az Arab-félszigeten.

105 Az Abu Abbasz Brigádokat az USA is terrorszervezetnek nyilvánította már 2017-ben, azonban a szaúdi vezetésü koalíció azóta is támogatja és fegyverekkel látja el.

106 Oshkosh L-ATV könnyü többcélü harci szállító jármü.

107 Megjegyzendő, hogy ezeket a fejlett eszközöket szinte minden esetben viszonylag rövid időn belül elvesztette az adott szervezet (megsemmisültek vagy müködésképtelenné váltak), elsősorban a technika kezeléséhez szükséges szaktudás hiányának következtében.

108 Akna elleni védelemmel ellátott szállítójármű. 
volt, amely az amerikai gyártó texasi telephelyéről az Abu Dhabiba történő transzfert jelezte. ${ }^{109}$ A Pentagon szóvivője, John Michael szerint: „Az Egyesült Államok nem hatalmazta fel Szaúd-Arábiát vagy az Egyesült Arab Emirátusokat bármely felszerelés továbbadására bármely harmadik fél számára Jemenen belül." ${ }^{110} \mathrm{~A}$ konkrét eset azért is vetett fel kérdéseket, mert az amerikai haderő katonái más hadszíntereken éppen az érintett Oshkosh és MRAP járművekkel vesznek részt a műveletekben, és a technológia esetleges ellenséges kézbe kerülése veszélyeztethetné az aknák és az úgynevezett IED-eszközök ${ }^{111}$ elleni védelem hatékonyságát, ezáltal pedig az amerikai személyzet biztonságát. Mindenesetre nem látszik annak jele, hogy ezek az esetek és a nemzetközi kritikák bármilyen változást hoztak volna a koalíciós erők azon hozzáállásában, ami a fegyverek harmadik fél számára való átadásának korlátozását illeti.

\section{Felhasznált irodalom}

Al-Dawsari, Nadwa: Running around in circles: How Saudi Arabia is losing its war in Yemen to Iran. Middle East Institute, 2020. március 3. Online: www.mei.edu/ publications/running-around-circles-how-saudi-arabia-losing-its-war-yemen-iran Brimelow, Ben: Saudi Arabia has the best military equipment money can buy - but it's still not a threat to Iran. Business Insider, 2017. december 16. Online: www. businessinsider.com/saudi-arabia-iran-yemen-military-proxy-war-2017-12

Browning, Noah: Houthi missile arsenal holds a key to future Yemen peace. Reuters, 2016. november 22. Online: www.reuters.com/article/us-yemen-security-missiles-analysis/houthi-missile-arsenal-holds-a-key-to-future-yemen-peace-idUSKB$\mathrm{N} 13 \mathrm{H} 1 \mathrm{UU}$

Chuanren, Chen - Chris Pocock: Saudi Arabia buying and building Chinese armed drones. Aviation International News, 2017. április 12. Online: www.ainonline. com/aviation-news/defense/2017-04-12/saudi-arabia-buying-and-building-chinese-armed-drones

Davidson, Helen - Christopher Knaus: Australian weapons shipped to Saudi and UAE as war rages in Yemen. The Guardian, 2019. július 25. Online: www.theguardian. com/australia-news/2019/jul/25/australian-weapons-shipped-to-saudi-anduae-as-war-rages-in-yemen

Defence Security Cooperation Agency: Kingdom of Saudi Arabia - M1A2S Saudi Abrams Main Battle Tanks and M88Al/A2 Heavy Equipment Recovery Combat Utility Lift Evacuation System (HERCULES) Armored Recovery Vehicles (ARV). (2016. augusztus 9.). Online: www.dsca.mil/major-arms-sales/kingdom-saudi-arabia-m1a2s-saudi-abrams-main-battle-tanks-and-m88ala2-heavy

Direction de Renseignement Militaire: Yémen - Situation sécuritaire. Paris, (2018. szeptember 25.). Online: www.documentcloud.org/documents/5838298-Yemen-Papers.html

\footnotetext{
109 Nima Elbagir et al.: Sold to an ally, lost to an enemy. CNN, 2019. február.

110 Elbagir et al. (2019): i. m.

111 Improvizált robbanóeszközök.
} 
Elbagir, Nima - Salma Abdelaziz - Mohamed Abo El Gheit - Laura Smith-Spark: Sold to an ally, lost to an enemy. CNN, 2019. február. Online: https://edition.cnn.com/ interactive/2019/02/middleeast/yemen-lost-us-arms/

Emmons, Alex: Secret report reveals saudi incompetence and widespread use of U.S. weapons in Yemen. The Intercept, 2019. április 15. Online: https://theintercept. com/2019/04/15/saudi-weapons-yemen-us-france/

Fisher, Max - Schmitt, Eric - Carlsen, Audrey - Browne, Malachy: Did American missile defence fail in Saudi Arabia? Online: www.nytimes.com/interactive/2017/12/04/ world/middleeast/saudi-missile-defense.html?_r=0

Houthis launch air attacks on Saudi capital. The Guardian, (2020. március 30.). Online: www.theguardian.com/world/2020/mar/30/yemen-houthis-launch-air-attackson-saudi-capital-riyadh

Király István Mihály: Szaúd-Arábia és Irán katonai képességeinek, védelmi iparának és védelmi költségvetésének összehasonlító elemzése. Nemzet és Biztonság, 11. (2018), 1. 100-114. Online: https://doi.org/10.32576/ nb.2018.1.7

Knights, Michael: Lessons from the UAE war in Yemen. Lawfare, 2019. augusztus 18. Online:www.lawfareblog.com/lessons-uae-war-yemen

Maletta, Giovanna: Legal challenges to EU member states's arms exports to Saudi Arabia: Current status and potential implications. Stockholm International Peace Research Institute - SIPRI, 2019. június 28. Online: www.sipri.org/commentary/ topical-backgrounder/2019/legal-challenges-eu-member-states-arms-exports-saudi-arabia-current-status-and-potential

Ross, James: Yemen: Coalition blockade imperils civilians. UN should sanction senior Saudi leaders. Human Rights Watch, 2017 december 7. Online: www.hrw.org/ news/2017/12/07/yemen-coalition-blockade-imperils-civilians

Sabbagh, Dan: Don't let Saudi arms ship dock in UK, say campaigners. The Guardian, 2020. február 5. Online: www.theguardian.com/uk-news/2020/feb/05/dont-letsaudi-arms-ship-dock-in-uk-campaigners-military-yemen-war

Saudi-led coalition's artillery shelling kills 17 in Yemen. People's Dispatch, 2019. december 27. Online: https://peoplesdispatch.org/2019/12/27/saudi-led-coalitions-artillery-shelling-kills-17-in-yemen/

Saul, Jonathan: Exclusive: Iran Revolutionary Guards find new route to arm Yemen rebels. Reuters, 2017. augusztus 1. Online: www.reuters.com/article/us-gulf-kuwait-iran-exclusive/exclusive-iran-revolutionary-guards-find-new-route-to-arm-yemen-rebels-idUSKBN1AH4I4

Townsend, Mark: British target training os Saudi air force 'did not stop Yemen atrocities' The Guardian, 2019. június 23. Online: www.theguardian.com/world/2019/ jun/23/british-training-saudi-air-force-atrocities-yemen

USA and France dramatically increase major arms exports; Saudi Arabia is largest arms importer, says. Stockholm International Peace Research Institute - SIPRI, (2020. március 9.). Online: www.sipri.org/media/press-release/2020/usa-and-france-dramatically-increase-major-arms-exports-saudi-arabia-largest-arms-importer-says

Weisgerber, Marcus: Saudi losses in Yemen war exposed by US tank deal. Defense One, 2016. augusztus 9. Online: www.defenseone.com/business/2016/08/ us-tank-deal-exposes-saudi-losses-yemen-war/130623/ 
Wezeman, Peter D.: Saudi Arabia, armaments and conflict in the Middle East. Stockholm International Peace Research Institute -SIPRI, 2018. december 14. Online: www.sipri. org/commentary/topical-backgrounder/2018/saudi-arabia-armaments-and-conflict-middle-east

Wezeman, Peter D. - Aude Fleurant - Alexandra Kuimova - Nan Tian - Siemon T. Wezeman: Trends in international arms transfers. Stockholm International Peace Research Institute - SIPRI, 2019. 